\title{
Learn from the Diesel
}

\section{Dear Reader,}

what can electrified powertrains learn from the "diesel"? The answer is short and simple: emotionalisation. We might recall that, until the early 1990s, diesel cars were seen as noisy, dirty and slow, used at best as workhorses by cost-conscious business customers such as taxi firms. After all, diesel engines were bought for their fuel economy and not for their driving dynamics. For that reason, diesel-powered cars played only a minor role in Germany. But then came turbocharging and direct injection: two technologies that turned the carthorse into a thoroughbred. The diesel changed from being an engine for cars with the dynamics of a tractor to a premium power unit that left its established gasoline-powered counterparts far behind in many disciplines. One example is its impressive low-end torque, providing plenty of "pulling power" for a comfortable, relaxed driving experience. It was this that made the diesel appealing to a much broader group of car buyers, with the result that diesel cars have accounted for almost $50 \%$ of all new cars registered in recent years.

Whether a diesel engine makes financial sense or not is often of secondary importance in the decision to buy, as customers tend to choose a diesel specifically because they like the way it drives. And this, in my opinion, is precisely what supporters of electrified powertrains should focus on. Simply having good fuel economy was not the reason why the diesel engine made its breakthrough, and low $\mathrm{CO}_{2}$ emissions alone will not help hybrid and electric drive systems either. What is needed is the targeted emotionalisation of hybrid and electric vehicles. Anyone who has driven a modern electric car will have marvelled at the incredible amount of torque available even from a standstill, and those who have experienced the boost function of a hybrid - either directly at the crankshaft or through an electrically supported compressor - will never want to do without the extra "kick" that it offers. I believe that marketing should do much more to convey these aspects, whether it is in advertising, in conversations with customers at car shows or in the car showroom itself.

Rationality and technical facts about $\mathrm{CO}_{2}$ reduction are all well and good, but someone who spends a lot of hard-earned cash on a car also wants be emotionally addressed. By the way, this problem can also be transferred 1:1 to discussions concerning CNG. Hardly any other drive concept offers such low costs per kilometre as a natural gas engine, and yet CNG vehicles are little more than a niche product and are seen by the general public as the eccentric choice of boring pennypinchers - which brings us back to the diesel of the pre-boom era. The solution might be a monovalent system approach which, thanks to a higher level of supercharging, would allow a higher specific power output than a comparable gasolinepowered engine - with driving dynamics and emotion as an added benefit.

Best regards,

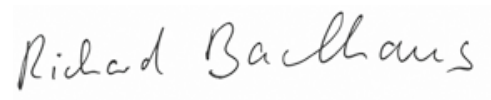

Richard Backhaus,

Vice-Editor in Chief

Wiesbaden, 2 February 2015

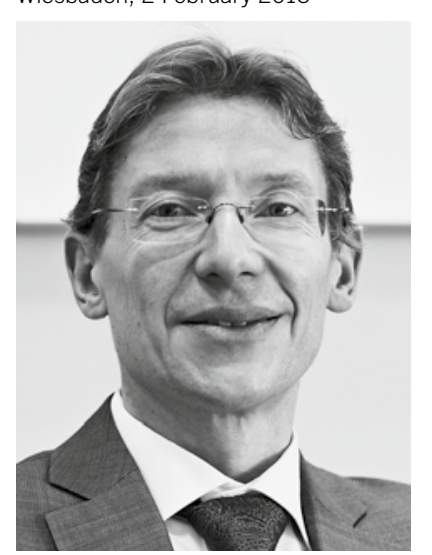

